\title{
Penerapan Media Film Dokumenter untuk Meningkatkan Hasil Belajar Sejarah Indonesia pada Siswa
}

\author{
Karino \\ SMA Negeri 1 Sungai Penuh
}

\begin{abstract}
Abstrak
Tujuan penelitian tindakan kelas ini adalah untuk meningkatkan hasil belajar siswa dalam memahami konsep faktual dan nilai-nilai kejuangan dan tuntunan moral bangsa dengan memanfaatkan media film dokumenter pada Siswa. Jenis penelitian ini termasuk dalam jenis penelitian tindakan kelas (PTK). Pengumpulan data yang dilakukan dalam penelitian ini adalah data hasil pekerjaan siswa dalam kegiatan mengerjakan tes tertulis pilihan ganda. Dalam penelitian ini penulis menggunakan dua teknik pengumpulan data, yaitu teknik tes dan teknik nontes. Teknik analisa data yang digunakan adalah teknik analisa data deskriptif. Hasil penelitian menunjukkan bahwa penerapan pendekatan saintifik dengan media film dokumenter untuk meningkatkan hasil belajar Sejarah Indonesia materi pokok Indonesia Merdeka dapat meningkatkan aktivitas belajar siswa.
\end{abstract}

Keywords: Penelitian tindakan kelas, media film dokumenter, hasil belajar.

\section{PENDAHULUAN}

Pada dasarnya pendidikan laksana eksperimen yang tidak pernah selesai sampai kapan pun sepanjang ada kehidupan umat manusia di dunia ini. Karena pendidikan merupakan bagian dari kebudayaan (Juanda, 2010; Mardotillah \& Zein, 2017) dan peradaban manusia yang terus berkembang sejalan dengan pembawaan manusia yang memiliki potensi kreatif dan inovatif dalam segala bidang kehidupan.

Menurut UU No. 20 Tahun 2003 pasal 3; berkembangnya potensi peserta didik agar menjadi manusia yang beriman dan bertaqwa kepada Tuhan Yang Maha Esa, berakhlak mulia, sehat, berilmu, cakap, kreatif,mandiri dan menjadi warga negara yang demokratis serta bertanggung jawab. Sedangkan tujuan pendidikan menengah adalah meningkatkan kecerdasan, pengetahuan, kepribadian, akhlak mulia, serta keterampilan untuk hidup mandiri dan mengikuti pendidikan lebih lanjut (Mahfuddin, 2013).

Melihat tujuan pendidikan nasional tersebut maka diperlukan pendidik yang profesional yang bertugas untuk merencanakan dan melaksanakan proses pembelajaran, melakukan pembimbingan dan pelatihan, serta dapat melakukan penelitian dan pengabdian kepada masyarakat.

Dalam proses pembelajaran sebagai pendidik diharapkan dapat menciptakan suasana pendidikan yang bermakna, menyenangkan (Wulandari, 2016), kreatif (Muhtadi, 2005), dinamis, dan dialogis (Muhtadi, 2005) 
serta mampu menjadi teladan bagi siswa. Sehingga guru sebagai pendidik dan sebagai pengajar diharapkan dapat melakukan pendekatan Pembelajaran yang Aktif, Inovatif, Efektif, dan Menyenangkan (PAIKEM) (Cahyono, 2010; Musfira, 2016; Ulfa, 2016) dengan menerapkan model-model pembelajaran yang bervariasi maupun penggunaan media pembelajaran yang inovatif agar dapat mengoptimalkan pembelajaran khususnya mata pelajaran Sejarah bagi siswa.

Mata pelajaran Sejarah dari dahulu hingga sekarang masih dianggap pelajaran yang membosankan bagi siswa (Alfian, 2011; Anshorulah, 2008). Dengan adanya anggapan bahwa materi mata pelajaran Sejarah hanyalah cerita mengenai masa lampau yang tidak ada gunanya untuk dipelajari saat ini sehingga menambah kurangnya motivasi siswa (Alie, 2013) untuk belajar Sejarah. Hal ini tentu saja berpengaruh dalam pencapaian prestasi hasil belajar siswa.

Fenomena diatas perlu adanya kreativitas guru untuk membuat media-media pembelajaran (Alwi, 2017) yang dapat membangkitkan motivasi siswa dalam belajar sejarah. Tetapi pada prakteknya seorang guru sering terbentur dengan minimnya sarana-prasarana yang ada di sekolah tempatnya mengajar (Nurahmat, 2019).

Dalam proses belajar mengajar kehadiran media pembelajaran mempunyai arti yang cukup penting (Ainina, 2014; Lestari, 2009; Ramli, 2015), dimana media tersebut sebagai alat bantu dalam proses belajar mengajar (Arsyad, 2011; Nugrahani, 2007). Ketidak jelasan dan kerumitan materi yang disampaikan kepada anak didik dapat disederhanakan dengan bantuan media. Tetapi penggunaan media sebagai alat bantu tidak bisa sembarangan harus memperhatikan dan mempertimbangkan tujuan (Fitri \& Ismulyati, 2016; Utami, Cahyono, \& Wicaksana, 2015). Untuk mengatasinya, media yang digunakan adalah sebuah film dokumenter tetapi dengan penggunaan yang optimal dimungkinkan dapat membantu guru dan siswa sehingga muncul motivasi siswa untuk mengoptimalisasi tujuan pembelajaran.

Materi pokok yang akan disajikan dalam penelitian tindakan kelas (PTK) pada kesempatan ini adalah Indonesia Merdeka. Peristiwa sekitar proklamasi kemerdekaan Indonesia yang menjadi inti tema tersebut sering kali oleh siswa dianggap peristiwa biasa-biasa saja dan ironisnya siswa hanya mengenang perlombaanperlombaan yang diselenggarakan dalam rangka memperingatinya.

Padahal peristiwa ini merupakan peristiwa yang sangat penting dan harus diketahui oleh setiap warga negara Indonesia. Kurangnya siswa dalam memahami makna, dan nilai-nilai patriotisme materi pokok tersebut diatas membuat guru tergugah untuk menggunakan berbagai media pembelajaran supaya siswa dapat memahami dan mengerti makna dan nilai-nilai dari peristiwa tersebut. Film dokumenter yang digunakan dalam pembelajaran Sejarah Indonesia berisi tentang rekaman peristiwa sejarah proklamasi kemerdekaan Indonesia. diharapkan dapat membantu siswa dalam memahami makna dan nilai serta tuntunan moral yang terkandung dalam materi pembelajaran tersebut.

Oleh karena itu penulis/peneliti perlu melakukan penelitian tindakan kelas penerapan metode pembelajaran pendekatan saintifik dengan media pembelajaran film dokumenter dengan judul "Penerapan Pedekatan Saintifik dengan Media Film Dokumenter Untuk Meningkatkan Hasil Belajar Sejarah Indonesia Materi Pokok Indonesia Merdeka Pada Siswa Kelas XI IPS 1 SMA Negeri 1 Sungai Penuh Tahun Pelajaran 2018/2019 “.

\section{METODE}

Penelitian ini termasuk dalam jenis penelitian tindakan kelas (PTK), yaitu sebuah kegiatan penelitian yang dilakukan di dalam kelas sasaran dengan memanfaatkan interaksi, kolaborasi antara peneliti dengan kelas sasaran (dalam hal ini siswa). Subjek penelitian adalah guru dan obyek sekaligus subyek penelitian ini adalah seluruh siswa kelas XI IPS 1 SMA Negeri 1 Sungai Penuh Provinsi Jambi pada tahun ajaran 2018/2019 sebanyak 27 orang siswa.

Penelitian ini dilaksanakan dalam dua siklus, yaitu siklus I dan siklus II. Sebelum dilaksanakan tindakan siklus I tersebut, peneliti melaksanakan tes pra siklus untuk mengetahui pemahaman siswa terhadap materi pokok Indonesia Merdeka dengan tes tertulis pilihan ganda. Siklus I digunakan sebagai refleksi untuk melakukan penelitian di siklus II, sedangkan siklus II bertujuan untuk mengetahui peningkatan hasil belajar siswa setelah dilakukan perbaikan pada proses pelaksanaan proses belajar mengajar yang didasarkan pada refleksi siklus I. Secara garis besar terdapat empat tahapan yang lazim dilalui dalam penelitian tindakan kelas dalam setiap siklus, yaitu perencanaan, pelaksanaan tindakan, pengamatan/observasi, dan refleksi. 
Pengumpulan data yang dilakukan dalam penelitian ini adalah data hasil pekerjaan siswa dalam kegiatan mengerjakan tes tertulis pilihan ganda. Dalam penelitian ini penulis menggunakan dua teknik pengumpulan data, yaitu teknik tes dan teknik nontes.

Teknik tes digunakan untuk mengetahui pemahaman terhadap materi pelajaran dengan menggunakan pendekatan saintifik media pembelajaran film dokumenter. Tes digunakan untuk mengetahui tingkat pemahaman peserta didik terhadap materi pelajaran sehingga dapat dihasilkan data yang dapat mendukung proses penelitian. Instrumen tes yang diberikan berupa perintah kepada peserta didik untuk mengerjakan tes tertulis pilihan ganda yang disediakan oleh penulis.

Teknik analisa data yang digunakan adalah teknik analisa data deskriptif. Fungsi teknik analisa data yang digunakan untuk memperoleh gambaran tentang hasil belajar. Ketuntasan belajar di kelas XI IPS 1 SMA Negeri 1 Sungai Penuh sebesar 75, berdasarkan KKM yang telah disepakati dalam Kurikulum 2013 untuk individu yaitu ketuntasan hasil belajar siswa jika siswa mendapat nilai $\geq 75$.

Kriteria untuk mengukur tingkat pencapaian keberhasilan pembelajaran dalam evaluasi dinyatakan telah mencapai tujuan pembelajaran jika total jumlah anak yang mampu menguasai mata pelajaran Sejarah Indonesia materi pokok Indonesia Merdeka diatas $75 \%$. Dan proses perbaikan pembelajaran dinyatakan telah mencapai tujuan pembelajaran jika jumlah siswa yang faham mata pelajaran Sejarah Indonesia materi pokok Indonesia Merdeka diatas $75 \%$.

\section{HASIL PENELITIAN DAN PEMBAHASAN}

Hasil penelitian yaitu menjelaskan bagaimana penerapan pendekatan saintifik dengan media film dokumenter untuk meningkatkan hasil belajar Sejarah Indonesia materi pokok Indonesia Merdeka pada siswa kelas XI IPS 1 SMA Negeri 1 Sungai Penuh Semester Genap Tahun Pelajaran 2018/2019.

\section{Pembahasan Hasil Penelitian Siklus I}

Pembahasan hasil penelitian siklus I meliputi (a) analisis, (b) sintesis, dan (c) evaluasi. Pembahasan hasil penelitian pada siklus I peneliti sajikan sebagai berikut:

\section{Analisis}

Dari hasil data yang didapat oleh observeri, maka proses belajar mengajar yang telah dilakukan dianalisis: proses pembelajaran kurang lancar dan kurang menyenangkan sehingga siswa kurang antusias, kurang bersemangat dalam menerima pelajaran, serta guru tidak menggunakan pendekatan, strategi, metode atau media pembelajaran yang variatif.

2. Sintesis

Pada siklus ini dari proses pembelajaran yang telah dilakukan mulai dari perencanaan sampai pada akhir kegiatan, ternyata belum dapat meningkatkan pemahaman siswa sesuai dengan apa yang diharapkan oleh guru. Hal ini disebabkan karena masih adanya kelemahan yang ditemui sehingga masih menjadi rintangan dalam mencapai peningkatan hasil belajar siswa sehingga perlu dilakukan pembelajaran pada siklus II selanjutnya.

3. Evaluasi

Berdasarkan hasil data pada proses pembelajaran pada siklus I ini, memperlihatkan bahwa proses pembelajaran Sejarah Indonesia materi pokok Indonesia Merdeka memperlihatkan tingkat keberhasilan belajar siswa secara klasikal masih di bawah standar (tidak tuntas) yaitu 15 orang siswa dari jumlah total 27 orang siswa dan baru 12 orang siswa dinyatakan tuntas belajar. Nilai rata-rata kelas 73,31 (masih dibawah KKM) meskipun hampir mendekati KKM 75, dan ketuntasan belajar berada pada angka 56,25\% masih di bawah standar yang telah disepakati, maka untuk itu perlu dilakukan kembali Siklus II.

\section{Pembahasan penelitian siklus II}

Pembahasan hasil penelitian siklus II meliputi (a) analisis, (b) sintesis, dan (c) evaluasi. Pembahasan hasil penelitian pada siklus II peneliti sajikan sebagai berikut:

1. Analisis

Setelah diadakan siklus II yang diikuti oleh seluruh siswa pada kelas yang sama dan dilakukan sesuai dengan perencanaan dan skenario pembelajaran, maka proses pembelajaran berjalan dengan baik, lancar dan kondusif. 


\section{Sintesis}

Setelah diadakan siklus II yang diikuti oleh seluruh siswa pada kelas yang sama dan dilakukan sesuai dengan perencanaan dan skenario pembelajaran, maka proses pembelajaran berjalan dengan baik, lancar dan kondusif.

\section{Evaluasi}

Hasil evaluasi proses perbaikan pembelajaran Sejarah Indonesia materi pokok Indonesia Merdeka Kelas XI IPS 1 SMA Negeri 1 Sungai Penuh dengan penerapan pendekatan saintifik dengan media film documenter untuk meningkatkan hasil belajar siswa kelas XI IPS 1 SMA Negeri 1 Sungai Penuh pada mata pelajaran Sejarah Indonesia materi pokok Indonesia Merdeka, membuktikan bahwa perubahan peningkatan hasil belajar siswa memperoleh nilai rata-rata kelas 60,94 sebesar 28,13\% pada kondisi awal (pra siklus) masih rendah, berubah nilai rata-rata kelas meningkat secara signifikan menjadi 84,44 sebesar $78.13 \%$ pada siklus II.

\section{KESIMPULAN}

Berdasarkan hasil penelitian dan pembahasan, diperoleh kesimpulan sebagai berikut: 1) Penerapan pendekatan saintifik dengan media film dokumenter untuk meningkatkan hasil belajar Sejarah Indonesia materi pokok Indonesia Merdeka dapat meningkatkan aktivitas belajar siswa kelas XI IPS 1 SMA Negeri 1 Sungai Penuh terbukti pada siklus I skor rata-rata hasil aktivitas belajar siswa 73,31 dengan ketuntasan belajar klasikal sebesar 56,26\%, meningkat pada siklus II yaitu skor rata-rata sebesar 84,44 dengan persentasi ketuntasan belajar (KKM) sebesar 78,13\%; 2) Penerapan pendekatan saintifik media film dokumenter untuk meningkatkan hasil belajar Sejarah donesia materi pokok Indonesia Merdeka dapat meningkatkan hasil belajar Sejarah Indonesia materi pokok Indonesia Merdeka siswa kelas XI IPS 1 SMA Negeri 1 Sungai Penuh terbukti pada siklus I skor rata-rata hasil belajar siswa 73,31 dengan 15 orang siswa belum tuntas dan 12 orang siswa tuntas dari jumlah total 27 orang siswa, meningkat pada siklus II yaitu 84,44 dengan 25 orang siswa yang tuntas dan 2 orang siswa.tidak tuntas.

\section{REFERENSI}

Ainina, I. A. (2014). Pemanfaatan media audio visual sebagai sumber pembelajaran sejarah. Indonesian Journal of History Education, 3(1).

Alfian, M. (2011). Pendidikan Sejarah dan Permasalahan yang Dihadapi. Khazanah Pendidikan, 3(2).

Alie, N. H. (2013). Penggunaan model pembelajaran kooperatif tipe nht untuk meningkatkan hasil belajar siswa kelas x2 sma neg. 3 gorontalo pada materi jarak pada bangun ruang. Jurnal Entropi, 8(01).

Alwi, S. (2017). Problematika guru dalam pengembangan media pembelajaran. ITQAN: Jurnal Ilmu-Ilmu Kependidikan, 8(2), 145-167.

Anshorulah, R. (2008). Efektifitas metode mnemonik dalam meningkatkan daya ingat siswa pada mata pelajaran sejarah di MTS Persiapan Negeri Kota Batu. Universitas Islam Negeri Maulana Malik Ibrahim.

Arsyad, A. (2011). Media pembelajaran. Jakarta: Raja Grafindo Persada.

Cahyono, Y. (2010). Upaya Mengatasi Kesulitan Belajar Matematika Melalui Pendekatan Pembelajaran Aktif Inovatif Kreatif Efektif Dan Menyenangkan (PAIKEM) Pada Siswa Kelas VII SMP Negeri 2 Gemolong (PTK Pembelajaran Matematika di Kelas VII SMP Negeri 2 Gemolong). Universitas Muhammadiyah Surakarta.

Fitri, H., \& Ismulyati, S. (2016). Peningkatan Hasil Belajar Siswa dengan Media Animasi pada Materi Koloid di Kelas XI IPA3 SMAN 1 Unggul Darul Imarah Aceh Besar. Jurnal Edukasi Kimia (JEK), 1(1), 19-24.

Juanda, J. (2010). Peranan Pendidikan Formal dalam Proses Pembudayaan. Lentera Pendidikan: Jurnal Ilmu Tarbiyah Dan Keguruan, 13(1), 1-15.

Lestari, H. P. (2009). Pemanfaatan media pembelajaran berbasis ICT dalam pembelajaran geometri. Pendidikan Matematika UNY.[Online]. Tersedia: Staff. Uny. Ac. Id/Sites/Default/Files/132280881/Pemanfaatan\% 20Media\% 20Pembelajaran\% 20Berbasis\% 20ICT\% 20dalam\% 20Pembelajaran\% 20Geometri_0. Pdf.

Mahfuddin, A. (2013). Kurikulum Tingkat Satuan Pendidikan (KTSP) Sekolah Menengah Atas (SMA). Allemania, 2(2), 152-158.

Mardotillah, M., \& Zein, D. M. (2017). Silat: Identitas Budaya, Pendidikan, Seni Bela Diri, Pemeliharaan Kesehatan. Jurnal Antropologi: Isu-Isu Sosial Budaya, 18(2), 121-133.

Muhtadi, A. (2005). Menciptakan iklim kelas (Classroom Climate) yang kondusif dan berkualitas dalam proses pembelajaran. Majalah Ilmiah Pembelajaran, 1(2).

Musfira, M. (2016). Implementasi Pendekatan PAIKEM (Pembelajaran Aktif, Inovatif, Kreatif, Efektif, dan 
Menyenangkan) Untuk Meningkatkan Keterampilan Berpikir Kreatif Peserta Didik Kelas X2 SMA Negeri 1 Bissappu. Pascasarjana.

Nugrahani, R. (2007). Media pembelajaran berbasis visual berbentuk permainan ular tangga untuk meningkatkan kualitas belajar mengajar di sekolah dasar. Lembaran Ilmu Kependidikan, 36(1).

Nurahmat, I. (2019). Kurangnya Sarana dan Prasarana Sekolah Di Kota Padang.

Ramli, M. (2015). Media Pembelajaran Dalam Perspektif Al-Qur'an Dan Al-Hadits. Ittihad Jurnal Kopertais Wilayah XI Kalimantan, 13(23), 133-134.

Ulfa, S. (2016). Pengaruh Model Paikem (Pembelajaran Aktif, Inovatif, Kreatif, Efektif, Dan Menyenangkan) Terhadap Minat Belajar Siswa (Studi Kasus Mata Pelajaran Akuntansi Pada Kelas XI Akuntansi SMK Pasundan 3 Bandung Semester Genap Tahun Ajaran 2015-2016). FKIP UNPAS.

Utami, R. D., Cahyono, B. E. H., \& Wicaksana, M. F. (2015). Penggunaan Media Monopoli Bahasa Sebagai Media Pembelajaran Membaca Komprehensif Pada Siswa SMP Negeri 1 Nguntoronadi Kabupaten Magetan. Widyabastra: Jurnal Ilmiah Pembelajaran Bahasa Dan Sastra Indonesia, 3(1), 33-41.

Wulandari, D. (2016). Model Pembelajaran yang Menyenangkan Berbasis Peminatan. Jurnal Inspirasi Pendidikan, 6(2), 851-856. 